\title{
A Case of Renal Metastasis from Follicular Thyroid Carcinoma Mimicking Renal Cell Carcinoma
}

\author{
Ki Ju Cho', Jeong Seok Hwa ${ }^{2}$, Gyung Hyuck Ko ${ }^{2}$, and Jung Je Park ${ }^{1}$ \\ ${ }^{1}$ Department of Otolaryngology and Institute of Health Sciences, ${ }^{2}$ Urology and Patholgy, School of Medicine, \\ Gyeongsang National University, Jinju, Korea
}

\author{
신장 세포 암종으로 오인된 신장전이 갑상선 여포암 \\ 조기주 ${ }^{1} \cdot$ 화정석 $^{2} \cdot$ 고경혁 $^{2} \cdot$ 박정제 $^{1}$ \\ 경상대학교 의학전문대학원 이비인후과학교실, ${ }^{1}$ 비뇨기과학 및 병리학교실
}

\author{
Received December 14, 2015 \\ Revised February 4, 2016 \\ Accepted February 14, 2016 \\ Address for correspondence \\ Jung Je Park, MD, PhD \\ Department of Otolaryngology \\ and Institute of Health Sciences, \\ School of Medicine, \\ Gyeongsang National University, \\ 501 Jinju-daero, Jinju 52828, Korea \\ Tel $+82-55-750-8698$ \\ Fax $+82-55-759-0613$ \\ E-mail capetown@hanmail.net
}

Follicular thyroid carcinoma is the second most common form of thyroid cancer. It accounts for 10 percent of all thyroid cancer, and is found three times more frequently in men than in woman. It is well known that follicular thyroid carcinoma usually occurs in regions where it is hard for people to intake iodine. Most follicular thyroid carcinomas occur asymptomatically but occasionally reveal as masses in the thyroid nodules. The occurence of metastasis of follicular thyroid cancer in the lymph node is less than $10 \%$, which is relatively low compared to that of papillary cancer. Follicular carcinomas are metastasized hematogenously and are common in the bone, liver, lung and brain. It is especially rare for metastatic follicular thyroid cancer to be diagnosed as renal tumor. We recently experienced and further investigated a case of follicular thyroid carcinoma that metastasised to the kidney in a 57-year-old woman, who had had abdominal distension. We report this case with a review of the reference.

Korean J Otorhinolaryngol-Head Neck Surg 2017;60(1):30-3

Key Words Follicular thyroid carcinoma $\cdot$ Kidney metastasis.

\section{서 론}

갑상선 여포암은 전체 갑상선암 중 두 번째로 흔한 유형이 다. 갑상선암 중 약 $10 \%$ 를 차지하며 주로 50 대에 흔하고 여 성에서 남성보다 3 배 더 많이 발견된다. 갑상선 여포암은 특 히 요오드를 섭취하기 어려운 지역에서 많이 발생하는 것으 로 알려져 있다. 갑상선 여포암은 대부분 무증상으로 우연히 발견된 갑상선의 종괴로 발현된다. 갑상선 여포암의 림프절 전이는 $10 \%$ 미만으로 유두암에 비해 상대적으로 낮다. 여포 암은 주로 혈행성 전이를 하며 원격 전이율은 약 $20 \%$ 로 골 전이가 가장 흔하며 다음으로 자주 전이되는 장기는 간, 폐, 뇌이다. 신장의 종양에서 갑상선 여포암이 먼저 진단되는 경 우는 매우 드물다. 본 증례는 신장의 종괴를 제거한 후 병리 검사에서 신장으로 전이된 갑상선 여포암이 진단되어 갑상선
전절제술을 통해 원발부위를 확인한 증례를 경험하였기에 문헌 고찰과 함께 보고하는 바이다.

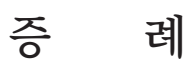

57세 여자 환자가 내원 일주일 전부터 발생한 복부불편감 과 부종을 주소로 응급실을 내원하였다. 과거력상 20년 전 B 형간염을 진단받았으나 치료는 받지 않고 있었고 최근에 한 약을 복용한적 있어 간경화 의증으로 본원 소화기 내과 후 컴 퓨터단층촬영을 시행하였고, 우측 신장의 하부에서 $3.5 \mathrm{~cm}$ 가량의 종양이 발견되었다(Fig. 1). 이후 환자는 신장 세포 암 종(renal cell carcinoma) 의심 하에 우측 근치적 신장절제술 을 시행하였고 $3.2 \times 3 \mathrm{~cm}$ 인 고형성의 연미색을 띠고 있는 종 괴가 발견되었다. 조직병리학적으로 hematoxylin \& eosin 염 


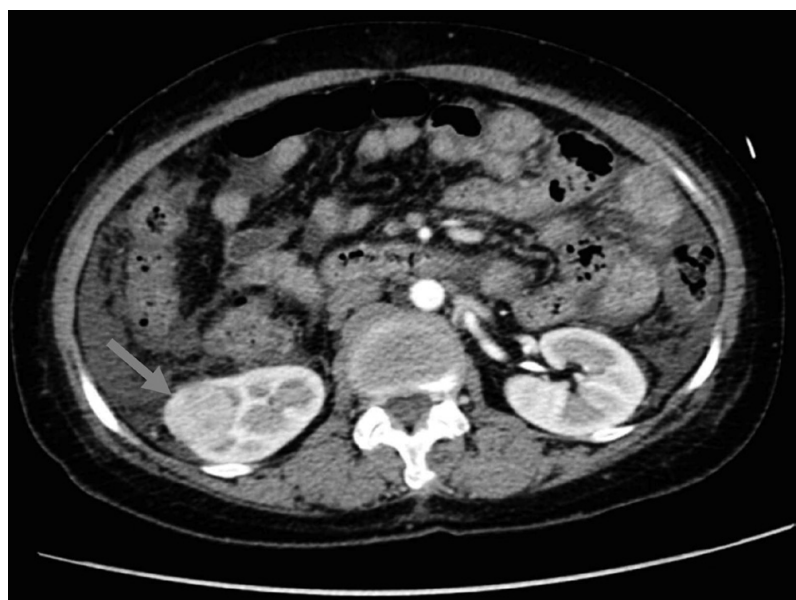

Fig. 1. Abdominal CT revealed a $3.2 \mathrm{~cm}$ well-defined mass in the right kidney (arrow).
색 조직표본에서 콜로이드를 포함하는 여포들로 구성되어 있 었고, 면역조직화학검사에서 갑상선전사인자-1(thyroid transcription factor-1, TTF-1)이 양성으로 나타났다(Fig. 2). 이 상의 소견으로 갑상선에서 신장으로 전이된 여포암으로 확진 되었고, 신장 정맥과 요로에서의 전이소견은 관찰되지 않았 다. 이후 시행한 갑상선 초음파검사에서 갑상선 우엽에서 2.1 $\mathrm{cm}$ 의 주변부 석회화를 동반한 결절과 좌엽에서 저음영의 결 절이 발견되어(Fig. 3A), 세침흡입세포검사를 시행하였으나 우엽의 석회화를 동반한 결절에서는 불충분한 세포소견, 좌 엽 결절에서는 여포성 결절 소견을 보였다. 갑상선 기능검사 결과는 T3 $82.02 \mathrm{ng} / \mathrm{dL}(80 \sim 170 \mathrm{ng} / \mathrm{dL})$, 유리 T4 $1.18 \mathrm{ng} /$ $\mathrm{dL}(0.80 \sim 2.10 \mathrm{ng} / \mathrm{dL})$, 갑상선자극호르몬 $0.78 \mathrm{uIU} /$ $\mathrm{mL}(0.3 \sim 5.0 \mathrm{uIU} / \mathrm{mL})$ 로 정상이었다. PET-CT에서 좌측갑상

Fig. 2. Histological findings revealed the tumor cells were arranged in well differentiated follicular pattern. Colloid-like materials were found in the intrafollicular space $(A)(H \& E \times 100)$. The positive immunohistological stain of TTF-1 (B) $($ TTF-1 $\times 100)$. TTF1: thyroid transcription factor-1.
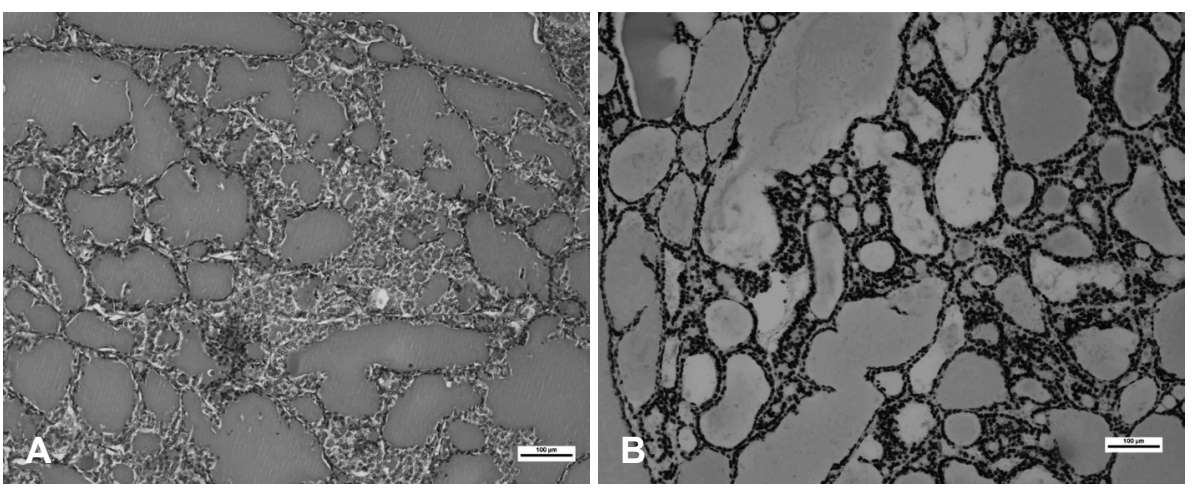

Fig. 3. Thyroid USG-FNA R1: $2.27 \times$ $1.56 \times 2.62 \mathrm{~cm}$, Rim calcified nodule (A) PET-CT: focal FDG uptake in thyroid gland left lobe (arrow) and no FDG uptake in right lobe calcified nodule (B).
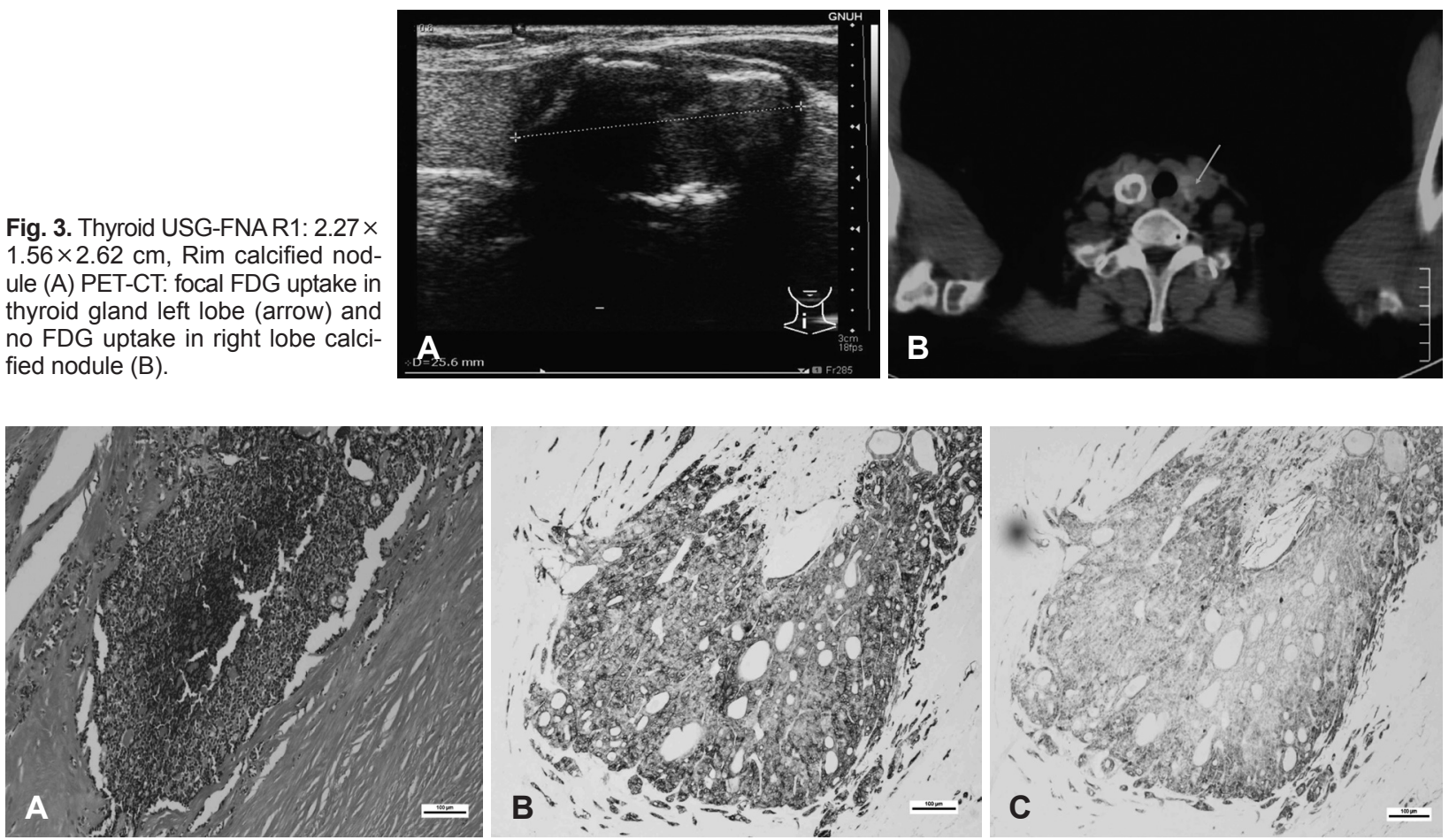

Fig. 4. Histological findings revealed the follicular carcinoma of the thyroid $(A, H \& E \times 100)$. The positive immunohistological stain of Galectin-3, cytokeratin $(C K) 19(B$, Gal-3 ×100) $(C, C K 19 \times 100)$. 
선에 섭취증가 소견이 관찰되었으나, 우측은 섭취증가 소견 은 보이지 않았다(Fig. $3 \mathrm{~B}$ ). 병리 소견 및 임상적 판단에 따 라 갑상선전절제술 및 중앙 림프절 절제술을 시행하였고, 갑 상선 우엽에 $3.2 \times 2.3 \mathrm{~cm}$ 의 경계가 좋은 석회화된 종괴가 관 찰되었다. 조직병리소견에서 갑상선 우엽에 석회화된 조직과 갑상선 피막(capsule) 침윤 없이, 혈관(vascular)을 침윤한 종 양이 관찰되었고, 면역조직화학검사에서 cluster of differentiation56 음성, galectin-3 양성, cytokeratin19 양성으로 갑 상선 여포암이 확진되었으며, 주위 림프절전이는 관찰되지 않 았다(Fig. 4). 전신 뼈 스캔(bone scan) 검사상 우측 4번 늑골 과 $\mathrm{T} 12, \mathrm{~L} 1$ 척추에서 섭취 증가 소견이 관찰되었으나, 추가적 인 병력청취상 1 년 전 넘어지면서 다친 부위와 일치하여 외상 에 의한 늑연골염로 진단되어 정기적으로 추적 관찰하기로 하였다. 환자는 현재 갑상선호르몬제로 thyroid stimulating hormone 억제 치료를 유지하면서 수술 후 3개월 뒤 방사선 요오드치료를 시행하였으며 현재 특이소견은 없는 상태이다.

\section{고 찰}

갑상선암의 신장 전이를 진단하는 방법으로는 $\mathrm{FDG}$ 양전자 방사단층촬영(fluorodeoxyglucose positron emission tomography), 자기공명영상(magnetic resonance imaging), 단일광 자 단층촬영(single photon emission computed tomography) 과 같은 영상의학적 진단 기법이 유용하다고 알려져 있다. ${ }^{122}$ 그러나, 본 증례의 환자의 경우에는 복부 불편감과 부종을 주소로 내원하여 복부 컴퓨터단층촬영(computed tomography)을 먼저 시행하였고, 우측 신장에서 부수적인 병소가 없 으며, 경계가 비교적 명확한 단일 종양이 발견되었기 때문에 일차 신장 세포 암종(primary renal cell carcinoma)을 우선 적으로 고려하였다. 앞서 기술한 영상의학적 진단 기법을 수
술 전에 고려하는 것이 감별진단에 도움이 되나, 실제 임상에 서 적용하기는 쉽지 않은 실정이다.

한편, 신장종양에서 조직학적으로 여포암의 형태를 보일 때 는 전이된 갑상선 여포암(renal metastasis of thyroid follicular carcinoma)과 갑상선 여포암 모양-신장암(thyroid follicular carcinoma-like renal tumor)을 감별하는 것이 중요하다. 갑상선 여포암 모양-신장암은 만성신우신염(chronic pyelonephritis), 폐쇄요로병증(obstructive uropathy) 또는 말기신부 전(end-stage renal disease) 환자들의 신장이 갑상선화(thyroidization)되어 발생하는 것으로 원위세관 위축(atrophic distal tubule)과 콜로이드 유리원주(colloid-like hyaline cast) 가 관찰되어 일부 갑상선의 조직학적 양상을 보인다. 하지만, 악성화 가능성이 낮고, 폐로 전이된 증례 이외에 다른 전이가 발견되지 않아 임상적 양상이 갑상선 여포암의 신장전이의 경 우와 구별된다. 갑상선 여포암 모양-신장암의 경우에는 갑상 선전절제술이 필요하지 않기 때문에 이것을 감별하는 것이 중요하다. 면역염색화학방법으로 감별이 가능한데, 신장으로 전이된 갑상선 여포암에서는 갑상선전사인자-1(TTF-1), 티로 글로불린(thyroglobulin)염색에서 양성이지만, 갑상선 여포암 모양-신장암에서는 음성이다. 또한, FDG 양전자 방사 단층 촬영(PET-CT)이나 전신 옥소 영상검사(I-131 whole body $\mathrm{scan}$ )를 시행하면 갑상선 여포암 모양-신장암에서는 갑상선에 특이소견이 관찰되지 않아 감별이 가능하다. ${ }^{3)}$ 본 증례의 경우 우측 신장종양 절제술 조직염색에서 여포암의 형태, 면역조직 검사에서 TTF-1 양성, 이후 갑상선절제술에서 동일한 형태의 병변이 관찰되어 신장으로 전이된 갑상선 여포암으로 진단할 수 있었다.

문헌에 따르면, 갑상선 암의 원격 전이율은 $1.4 \sim 6 \%$ 정도이 며, 대개 뼈(43\%), 폐(40\%), 종격동(32\%)에 전이된다. 신장으 로 전이되는 경우는 흔하지 않기 때문에 부검에서 발견되는

Table 1. Reported cases of renal metastasis from thyroid carcinomas

\begin{tabular}{|c|c|c|c|c|c|}
\hline Reference & Sex/age & Histology & Side & Interval (years) & Metastatic site \\
\hline 5 & $F / 44$ & Follicular & Bilateral & 3 & Lumbar vertebra \\
\hline 6 & $F / 49$ & Follicular & Bilateral & 18 & - \\
\hline 7 & $F / 66$ & Follicular & Left & 37 & - \\
\hline 8 & $\mathrm{~F} /-$ & Follicular & Right & 23 & - \\
\hline 9 & $\mathrm{~F} / 47$ & Follicular & Right & 7 & - \\
\hline 10 & $F / 91$ & Follicular & Left & - & - \\
\hline 11 & $F / 65$ & Follicular & Left & - & Lung, bone \\
\hline 12 & $M / 62$ & Follicular & Left & 9 & - \\
\hline 13 & $\mathrm{~F} / 78$ & Follicular & Right & 10 & - \\
\hline 14 & $F / 66$ & Follicular & Right & - & Bone (scalp), adrena \\
\hline 2 & $F / 76$ & Follicular & Right & 1 & - \\
\hline 4 & $F / 64$ & Follicular & Left & 0.5 & - \\
\hline This work & $F / 57$ & Follicular & Right & 0.5 & - \\
\hline
\end{tabular}


경우가 많고, 전체의 2.8 3.8\% 정도이다. ${ }^{4)}$ Medline과 google scholar 검색을 통해 현재까지 영문으로 작성된 문헌으로는 18 증례가 검색되었고, 그 중 갑상선 여포암이 신장으로 전이 된 경우는 12증례였다(Table 1).,4-14) 신장 전이는 좌측 5예, 우측 5 예, 양측 2예, 다발성 전이 3예였다. 모든 환자의 나이 가 40세 이상이었고, 여성 11명, 남성 1명으로 여성이 많았다. 대부분 복통(abdominal pain), 혈뇨(hematuria)가 주 증상 이었다. 대부분 경우 갑상선 여포암의 진단 이후, 전신 뼈 스캔 (bone scan) 검사에서 발견되는 것이 흔하며 평균적으로 전 이암이 발견되는 기간도 길다(평균 9년). 이것은 갑상선 암이 느리게 진행되는 특성의 결과로 여겨진다. 하지만, 과거 증례 의 경우 영상의학적 진단기술이 발달하지 않았고, 의료 접근이 용이하지 않았기 때문에 전이암이 발견되는 기간이 길어진 것 이라고도 생각해 볼 수 있다. 갑상선 여포암(follicular thyroid carcinoma)은 혈행성 전이를 하며, 혈청 티로글로불린(serum thyroglobulin)이 전이 또는 재발여부를 확인하는 데 유용한 지표가 된다.

치료는 갑상선 전절제술과 더불어 원격 전이부위의 수술적 절제 이후 방사선 요오드 치료(iodine-131 therapy)가 환자의 예후 및 5년 생존율을 높이는 데 좋은 것으로 알려져 있다.

대부분의 경우 세침흡입세포검사 등을 통해 갑상선 암을 진단하여, 갑상선 전절제술을 시행한 이후 추적 관찰에서 신 장 전이가 발견되는 증례가 많이 보고되고 있다. 하지만, 본 증 례는 신장에서 종양이 1차적으로 발견되어 신장 절제술 후 갑 상선 여포암으로 진단되어 역추적 검사결과 갑상선 결절이 발견되었고, 갑상선 절제술 후에 갑상선 여포암으로 진단된 것으로 아직 국내문헌보고가 없다. 또한, 갑상선 여포암의 폐, 종격동, 뼈로 전이가 아닌 일측성 신장 원격전이로, 여포암의 전신전이 특성을 보여주는 한 예로 생각된다.

\section{REFERENCES}

1) Liou MJ, Lin JD, Chung MH, Liau CT, Hsueh C. Renal metastasis from papillary thyroid microcarcinoma. Acta Otolaryngol 2005; 125(4):438-42.

2) Cheon M, Choi JY, Kim HK, Chung JH, Ko YH, Kim YE, et al. Renal metastasis from follicular thyroid carcinoma diagnosed by I-131 whole-body scan mimicking renal cell carcinoma on contrastenhanced computed tomography. Nucl Med Mol Imaging 2011; 45(1):72-5.

3) Insabato L, Ben-Dor D, Galliani CA, Lastilla G, Bisceglia M. Primary thyroid and thyroid-like follicular carcinoma of the kidney versus solitary metastatic carcinoma of the thyroid: a vexing issue. Virchows Arch 2009;454(6):717-8.

4) Xu H, Zeng W, Tang Y. Metastatic thyroid follicular carcinoma presenting as a primary renal tumor. Intern Med 2012;51(16):2193-6.

5) Takayasu H, Kumamoto Y, Terawaki Y, Ueno A. A case of bilateral metastatic renal tumor originating from a thyroid carcinoma. J Urol 1968;100(6):717-9.

6) Davis RI, Corson JM. Renal metastases from well differentiated follicular thyroid carcinoma: a case report with light and electron microscopic findings. Cancer 1979;43(1):265-8.

7) Johnson MW, Morettin LB, Sarles HE, Zaharopoulos P. Follicular carcinoma of the thyroid metastatic to the kidney 37 years after resection of the primary tumor. J Urol 1982;127(1):114-6.

8) Marino G, Cocimano V, Taraglio S, Testori O. [Metastasis of thyroid carcinoma. A rare case of secondary renal tumor]. Minerva Urol Nefrol 1991;43(2):85-8.

9) Ro HJ, Ha HK, Kim HS, Shinn KS. Renal metastasis from thyroid carcinoma visible as a hyperdense lesion on unenhanced CT. AJR Am J Roentgenol 1995;165(4):1018.

10) Lam KY, Ng WK. Follicular carcinoma of the thyroid appearing as a solitary renal mass. Nephron 1996;73(2):323-4.

11) Garcia-Sanchis L, Lopez-Aznar D, Oltra A, Rivas A, Alonso J, Montalar J, et al. Metastatic follicular thyroid carcinoma to the kidney: a case report. Clin Nucl Med 1999;24(1):48-50.

12) Moudouni SM, En-Nia I, Rioux-Leclerq N, Manunta A, Guille F, Lobel B. Follicular carcinoma of the thyroid metastasis to the kidney nine years after resection of the primary tumor. Ann Urol (Paris) 2002; 36(1):36-7.

13) Matei DV, Verweij F, Scardino E, Rocco B, Renne G, Tradati N, et al. Late solitary thyroid carcinoma metastasis to the kidney: a case report. Anticancer Res 2003;23(1B):561-4.

14) Kumar A, Nadig M, Patra V, Srivastava DN, Verma K, Bal CS. Adrenal and renal metastases from follicular thyroid cancer. Br J Radiol 2005;78(935):1038-41. 